\title{
215. 高エネルギーX線の吸収線量計算プログラム
}

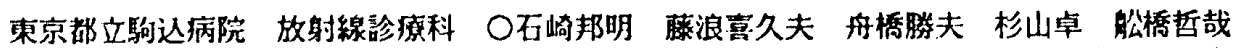

（目的）1986年に日本医放物理部会編藮により発表された、「吸収線量の標準測定法」に蕉拠した方法で、高エネルギー X線の線㔀計算ができるブログラムを開発する。

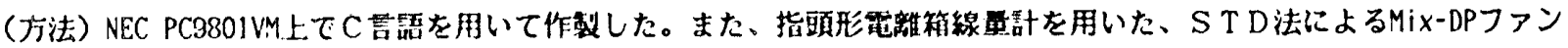
トム内での測定とした。

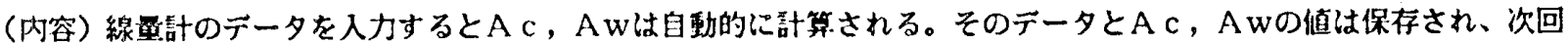
からは、線垔計のデー夕を入れる必要はない。続いて、测定条件を入力することにより、f med, P ion, Pd, k1,が計算さ れ、最終的に校正点吸収線骬Dcが求められる。

(結果) 標準测定法をまったく知らない者でも、必要データを入力するだけで、簡単にして、瞬時に吸収線量を求めるこ とができた。

\section{6. 高エネルギー電子線の吸収線量計算プログラム}

東京都立駒込病院 放射線診療科 ○石崎邦明 藤浪喜久夫 舟橋勝夫 杉山卓 忪橋哲哉

(目的）1986年に日本医放物理部会編集により発表された。「吸纡線量の標準测定法」に集扰した方法で、高エネルギー 電子線の線墨計算ができるブログラムを開発する。

(方法) NEC PC9801VM上でC言語を用いて作製した。また、指頭形及び、シャロー型電離箱線量計を用いた、S S D 法に よるMix-DPファントム内での測定とした。

(内容) 線量計のデータを入力するとA c , Awは目動的に計算される。そのデータとA c , Awの值は保存され、次回 からは、線量計のデータを入れる必要はない。続いて、測定条件を入力することにより、P D D、f med、Pion、Pf、kl、が 計算され、最終的に校正点吸収線量 D c が求められる。

(結果) 標準湘定法をまったく知らない者でむ、必要データを入力するだけで、簡単にして、瞬時に吸収線量を求めるこ とができた。

217. ウェッジ・フィルターによるT．P．R．の変化に関する研究

度応大 O砂凧正良 北川五十雄 龟田総合病院 滝田武信 東京医科大 橋本茂男 横山公一 筑 間晃比古 日大板橋病院 遠藤裕二 東京女子医大 获池峻 内山常男 帝京大 吾子俊敬 日本医大 井下隆弘 河原崎昇 国立がんセンター 林久貴 中里啓 黒沢秀雄 東京医科菌科大 久馬幸重 癌研病院 和久井 聖桑原秋夫 綾部煇 社会保険中央病院 坂井英章 鈴木達弥 関東莪信病院 馬場賁明

ウェッジ・フィルターを使用することによって T P Rが変化することはこれまでにもいくつかの報告がされている。 しかしながらその多くは比較的少数の茈置によって得られたデータであり T P Rの变化の割合の连いが真にエネルギー の違いによるものか単に装置間の差であるのか不確定である。今回我々はより多くの装置によってさらに詳しく、ウエ ッジ・フィルターによるTPRの变化について検討したので報告する。

218. T L -Sheetてこよる線旦严方布 奈良医大附属病院中放部・同がんセンター O白井明子 宇都文昭 过 佳彦 宇山茂樹 奈良医大附属がんセンター 腫場放射線科岩田和朗

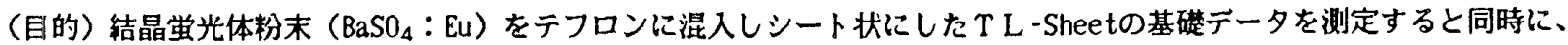
線量分布を作成し、臨床忍用の有用性について唡討する。

（方法） 1） $60 \mathrm{C}$ or 線を照射した T L-Sheetの発光光子数をカウントし、線量と発光量の関係をみた。 2) アニーリン グ温度を变化させ適当なアニーリング温度・時間について検討した。3）二次元読み取りシステムを使ってラルス治療 用 ${ }^{60} \mathrm{C}$ 。密封線源の線量分布図を作製した。4）TL-Sheetの常温での発光をX線フィルムに感光させ X線フィルムの 覑度を測定することにより、简便に線量分布図を作製する方法について娭討した。

(結果) 1) $10^{-3} \mathrm{cGyから} 10^{3} \mathrm{cGy}$ 間で線量とT L 発光光子数のグラフは直線になった。2）アニーリング温度が $200^{\circ} \mathrm{C}$ も10時間アニールすれば測定值の1/1000以下に消去できた。 3)二次元読み取りシステムは、一样に加熱することにつ いて問面があったが、グローカーブの全面箖を収集できれば解消できる。4）X線フィルムは测定できる線量のレンジ が狭いが、高線尖部と低線量部を合成することにより広い線量域を表示することむ可能である。 